\title{
REDUCTION IN TANGENTIAL FROST HEAVING FORCES BY THE PILE GEOMETRY CHANGE
}

\author{
Olga Tretiakova \\ Perm National Research Polytechnic University, \\ Komsomol'skii prospekt 29, Perm, 614990, Russia \\ Olga_wsw@mail.ru
}

\begin{abstract}
The subject of research is shallow foundations in seasonally freezing soils. One of the main reasons of reaching by foundation structures limit states in the strength and position stability is such hazardous natural phenomenon as the frost heave of soils. The goal of this work is reduction of the negative effect of frost heaving forces on shallow foundations. The technique is suggested for protection of underground structures from the effect of the freezing soil. A bored pile with the upper inverted cone was developed allowing partial neutralization of tangential frost heaving forces due to the vertical component of frost heaving forces acting normally to the pile lateral surface. Use of the method will lead to increase in the life of structures, decrease in their erecting and operating cost.
\end{abstract}

\section{Keywords}

Underground structures, frost heave, stress-strain state, normal and tangential forces, pulling load, bored pile, inverted cone.

\section{Introduction}

In cold regions at the seasonal decrease of air temperature cooling and freezing of the soil take place due to formation of ice lenses. It leads to increase in the soil mass volume and rising of its surface. When limiting expansion of the freezing soil by foundations of buildings and structures, significant frost heaving forces are developed. The hazardous natural process of the soil frost heave effects negatively on foundations of buildings and underground structures, causing the collapse of structures. This is noted by N. N. Morareskul (1950), B. I. Dalmatov (1954), V. D. Karlov (1998), O. R. Golli (2000), J. Modisette (2014), T. Kibriya (2015), M. Babaei (2016) and many other authors in their papers.

Existing methods of the shallow tunnels protection from the frost heaving effect provide for two basic approaches.

The first approach is in the corresponding calculation of structures which are capable to accept frost heaving forces without failure.

The second approach assumes decrease in the heaving forces effect on structures. Towards this end in view, various engineering and melioration procedures, as well as chemical, thermal and constructive methods are applied. However, the majority of them form an additional expense item for designing, mounting and operation. More rational is the search of solutions in the structure itself without additional elements and proce- dures. Methods of protection based on the use of effective structures are of interest.

Such structures can be pile foundations accepting all constant and temporary loads, including frost heaving forces. Pile foundations are capable to neutralize to some extent heaving forces causing differential rising of structures. Besides, the use of piles allows mechanizing the arrangement process of underground parts of buildings, reducing volumes of earthworks, maximally reducing sizes of trenches and excavation pits.

Stress-strain state of a pile in the seasonally freezing soil is defined mainly by tangential frost heaving forces taking pulling effect on a pile. Generally, tangential heaving forces are neutralized due to the friction on the pile lateral surface located in the thawed ground. It is ineffective, as it requires the significant length of piles. Reduction of the length is possible at decreasing heaving forces due to the optimization of the structural concept of piles, particularly of their shapes.

The calculation of piles for pulling forces was carried out by many authors (Dalmatov et al., 1975). Authors noted that stress-strain state of the pile and the soil around it at pulling loads significnalty depends on the structure and shape of the pile. Afterwards, the optimization of shapes of piles operating in clayly heaving soils was studied by $O$. P. Medvedeva (1992). The author considered piramydally prismatic driven piles with the lower cone narowing to the pile base. As a result of the work, the increased load-car- 
rying capacity of the piramydally prismatic pile on the action of tangential frost heaving forces, without taking into account normal forces, was designated. Simultaneously, studies of pyramid-shaped, trapezoid-shaped, lozenge-shaped foundations and foundations in the form of flattened cone directed with the larger base downward were carried out at the NIIOSP [Research institute of foundation and underground constructions] (1980). Later on, studies of operation of hollow biconical piles in heaving soils were carried out under the supervision of B.S. lushkov and A.B. Ponomarev (1987).

Wihhin these researches, D. S. Repetskii analyzed the stress-strain state of a single biconical pile under conditions of the soil frost heave (2011). A. O. Dobrynin stated decrease in the effect of frost heaving forces on the biconical-shaped pile cluster (2012). B. S. Yushkov supposed that forces, which retented the pile from rising, arised at the upper cone part of the pile. The author recommended the method for calculation of biconical pile with taking into accout the retenting force. The method complexity lies in need of the availability of data on the value of the soil surface rising at the frost heave. Among foreign researchers, George R. Newton (Amoco Production Company, 1972) presented a combined pile structure, suitable for permafrost regions, with the layer of water-saturated seasonally freezing soil.
The author concluded that when using this design solution, the force, which prevented rising of a pile, appeared in the process of freezing of the soil moisture. However, the value of retenting force factors and the pile designing technique are not given. Based on said, it is possible to conclude that researches in the field of pile shape optimization are advanced, but insufficient for the practical application and require the further development. To use suggested design solutions in the practical designing, calculation procedures of piles geometric characteristics with due account for actual hydrogeological conditions of a site are required. Technological elaborations for arrangement of piles are needed too.

\section{Materials and methods}

This paper deals with application of piles of the optimized design upon practical designing of structures on seasonally freezing soils. A pile design, resistant to the effect of frost heaving forces, and a method for its calculation are suggested. The design of suggested bored pile is implemented with the upper inverted cone, which has calculated geometric parameters. The design solution and the calculation diagram of the pile are shown in Figure 1.

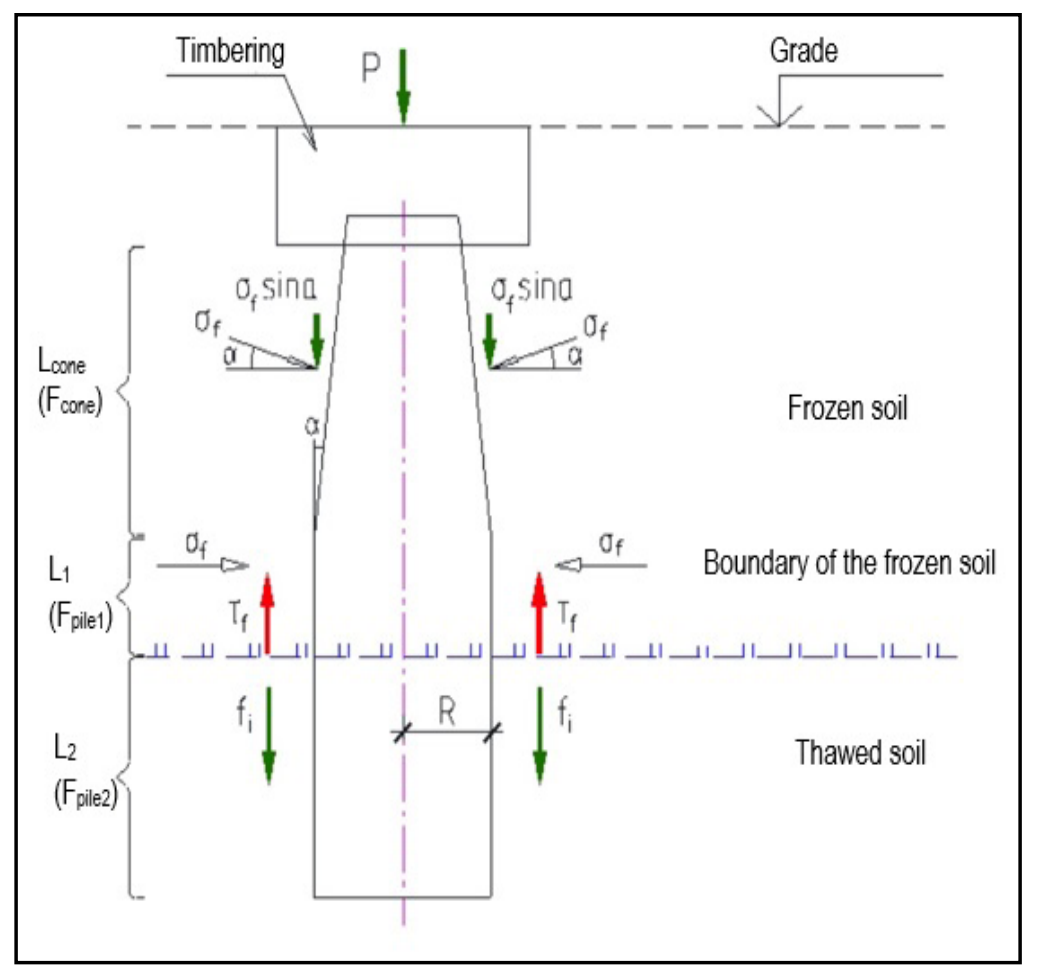

Figure 1. Design solution and calculation diagram of the pile with the upper inverted cone Pulling forces: $I_{f}$ - tangential frost heaving forces acting upon the pile section located in the frozen soil; forces retenting the pile in the soil: $P$ - the sum of external constant load and the own weight of the pile; $f_{i}$ - friction forces throughout the pile lateral surface in the thawed zone; $\sigma \sin \alpha$ - the component of the normal heaving forces within the inverted cone located in the frozen soil; $F_{\text {cone }}, F_{\text {pile }}, F_{\text {pile2 }}$, - areas of surfaces indicated on the diagram of pile sections 
The value of the pile rising (the vertical movement) is a criterion of the assessment of the pile resistence to the action of frost heaving forces. Rising of the pile foundation at the soil frost heave takes place mostly due to tangential forces, formation of which is determined by forces of soil adfreezing with the lateral surface of the foundation. Heaving forces, developing around the pile, tend to move the pile upwards. At that, the frozen soil sliding relative to the foundation occurs. Static bonds of the soil adfreeze with the foundation are decoupled. Dynamic bonds between the pile and the soil appear, determined by the resistence to the displacement of the frozen soil layer relative to the pile - tangential heaving forces.

The main idea of the research lies in the neutralization of tangential frost heaving forces by the pile design solution. In order to implement this idea, the objective was set to determine the force factor compensating pulling tangential forces due to the pile static potential. It is achieved by shaping the upper part of the pile as an inverted cone. The force factor is the vertical component of heaving forces acting normally to the lateral surface of the pile cone. This component appears due to the incline of the cone surface, it is directed from the daylight surface and partially neutralizes tangential forces, which are pulling the pile.

Scientific novelty of the research consists in the following: predicted, taken into accout by the calculation transformation of frost heaving forces, acting normally to the pile lateral surface, into the positive forces retenting the pile in the soil upon its pulling-out by tangential heaving forces; the value of the obtained retenting force is determined by the cone slope angle;

obtaining of expressions for geometrical parameters of the pile, which are optimal for the neutralization of tangential heaving forces.

The negative effect of vertical normal heaving forces on the timbering is prevented by arrangement under the timbering of the draining anti-heaving crush-rock pad with the inclination from piles. For protection from silting-up, the arrangement of a geoweb is possible. As an example, a pile pitching unit with the inverted cone in the base of a shallow tunnel is given (Figure 2). The coarse fraction crush-stone pad without compaction is provided. It ensures removal of the moisture, causing heaving, from the timbering. Uncompacted crush-rock pad, having some yielding, compensates the effect of the heaving soil, located lower than the crush-rock pad, on the timbering.

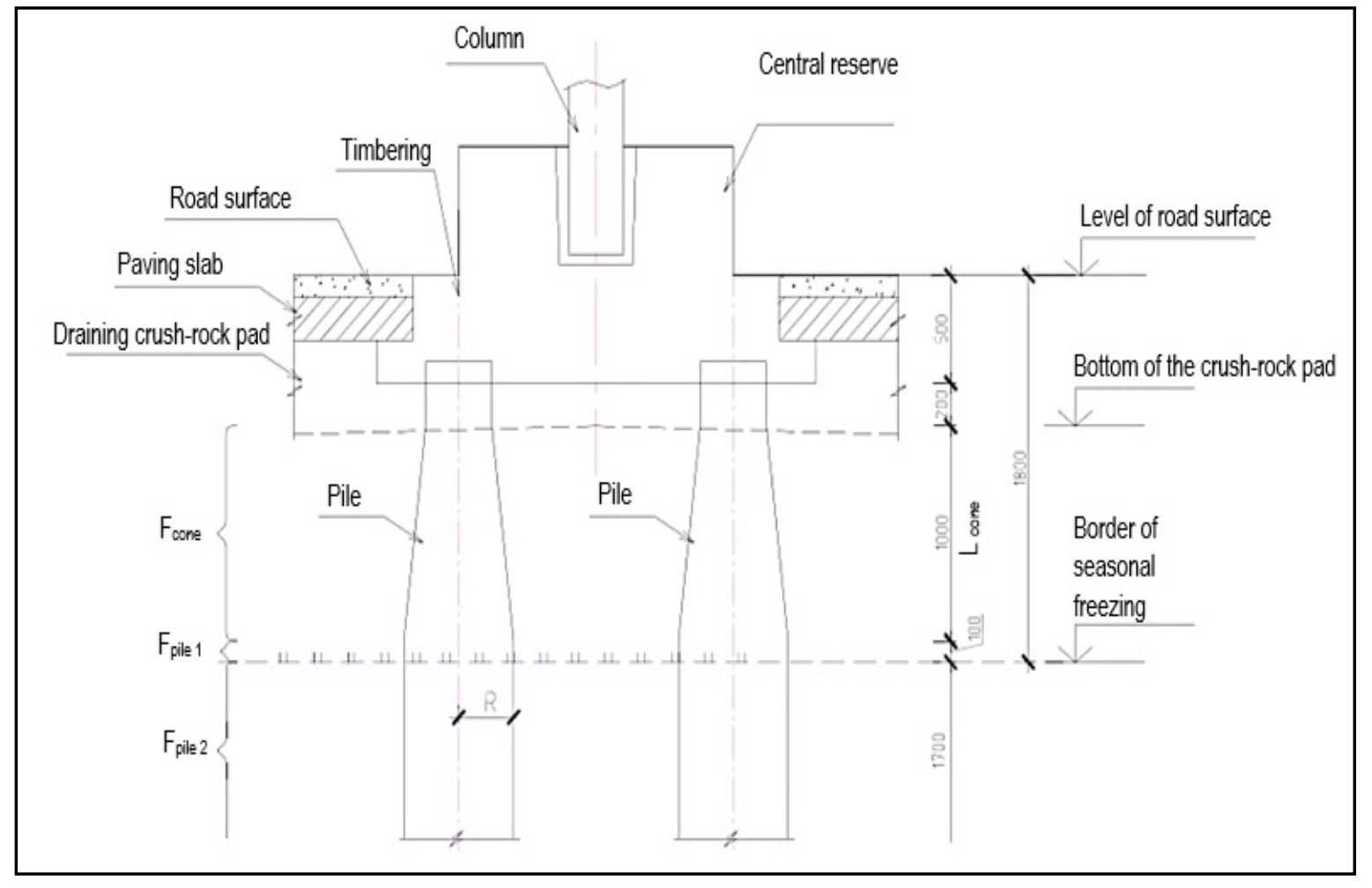

Figure 2. Pile pitching unit with the upper inverted cone in the base of a shallow tunnel 
Besides, the bored pile is easier to manufacture than a prefabricated pile upon the arrangement of structures distant from industrial sites for production of reinforced concrete elements.

In order to assess indices of the developed pile, theoretical and experimental researches were conducted.

Experimental researches in the pile with the upper inverted cone within the cone section proved occurence of the vertical component of frost heaving forces acting normally to the pile lateral surface. The experiment, carried out under conditions of the soil frost heave, showed that rising of the pile with a cone was less than rising of the pile without a cone. Besides, the reactive earth back pressure develops in the cone element upon the action of the tangential frost heaving forces, which also prevents the pile from rising.

Based on results of the experiment, it was also noted that, with the exception of listed main factors, several phenomena also take part in the formation of stress-strain state of the pile with the upper inverted cone. Thus, when pulling out the pile with the inverted cone, some volume of soil above it in the form of flattened heaving cone moves upwards together with the pile. This factor also exerts the retenting effect on the pile. Loads from the heaving cone, not taken into account in the calculation; forces of soil resistance to the uplift, acting throughout its lateral surface, create some strength reserve for the pile with the inverted cone.

According to results of the analytical calculation, the formula was obtained for the calculation of the pile cone slope angle which is optimal for bearing of frost heaving forces. The cone slope angle is selected in such a way as to ensure compliance of the vertical retenting component of normal heaving forces with that portion of the pulling tangential forces which are not compensated by the external load on the pile and its own weight. The value of the retenting component is calculated from the condition of equilibrium of the pile in the soil at its pulling-out by the tangential frost heaving forces.

Equation (1) of equilibrium of the pile in the soil:

$\tau_{f} \cdot F_{\text {cone }}+\tau_{f} \cdot F_{\text {pile } 1}-f_{i} \cdot F_{\text {pile } 2}-P-\sigma_{f} \cdot \sin \alpha \cdot F_{\text {cone }}=0$

where $\sigma f$ is the normal soil frost heave stress on the lateral surface of the pile;

$I_{f}$ is the tangential stress of the soil frost heave, exerting the pulling action on the pile;

$f_{i}$ is the calculated resistence of an i-layer of the soil on the lateral surface of the pile pier in the thawed soil, exerting the retenting effect on the pile;

$P$ is the sum of the external load and own pile weight;

$F_{\text {pile } 1}$ is the area of the pile lateral surface in the frozen soil without taking into account the cone;
$F_{\text {pile2 }}$ is the area of the pile lateral surface in the thawed soil;

$F_{\text {cone }}$ is the area of the pile lateral surface of the pile cone section;

$\alpha$ is the slope angle of the pile lateral surface of the pile cone section.

Let us transform the equation (1):

$$
\begin{aligned}
& \tau_{f} \cdot F_{\text {cone }}-\left(-\tau_{f .} \cdot F_{\text {pile } 1}+f_{i} \cdot F_{\text {pile } 2}+P\right)-\sigma_{f} \cdot \sin \alpha \\
& \cdot F_{\text {cone }}=0
\end{aligned}
$$

Let us designate the expression in brackets by ' $d$ ':

$d=-\tau_{f} \cdot F_{\text {pile } 1}+f_{i} \cdot F_{\text {pile } 2}+P$ form:

After substitution (3) the equation (2) will take the

$\tau_{f} \cdot F_{\text {cone }}-\sigma_{f} \cdot \sin \alpha \cdot F_{\text {cone }}-d=0$

Let us preliminarily determine the cone area (Figure 3) based on two assumptions:

1) $F_{\text {cone }}=2 \cdot \pi \cdot r_{\text {mid }} \cdot L$

2) $\operatorname{tg} \alpha \approx \sin \alpha$

The cone radius in the midsection according to Figure 3 will be:

$r_{\text {mid. }}=\frac{R+r}{2}=\frac{R+(R-x)}{2}=\frac{2 \cdot R-x}{2}=$

$R-0.5 \cdot x=R-0.5 \cdot L \cdot \sin \alpha$

where $\operatorname{tg} \alpha=\frac{x}{L} \Rightarrow x=L \cdot \operatorname{tg} \alpha=L \cdot \sin \alpha$

Then the cone area:

$F_{\text {cone }}=2 \cdot \pi \cdot L=2 \cdot \pi \cdot L \cdot(R-0.5 \cdot L \cdot \sin \alpha)=$

$=2 \cdot \pi \cdot L \cdot R-\pi \cdot L^{2} \cdot \sin \alpha$

Equation (4) after substitution of Fcone (5) and further transformation will take the form of the quadratic equation (6):

$\sigma_{f} \cdot \pi \cdot L^{2} \cdot \sin ^{2} \alpha+\left(-\sigma_{f} \cdot 2 \cdot \pi \cdot L \cdot R-\tau_{f} \cdot \pi \cdot L^{2}\right)$.

$\cdot \sin \alpha+\left(\tau_{f} \cdot 2 \cdot \pi \cdot L \cdot R-d\right)=0$

where $L$ is the length of the upper inverted cone of the pile; $R$ is the larger radius of the upper inverted cone.

Parameters of the quadratic equation:

$a=\sigma_{f} \cdot \pi \cdot L^{2}$

$b=-\sigma_{f} \cdot 2 \cdot \pi \cdot L \cdot R-\tau_{f} \cdot \pi \cdot L^{2}$ 


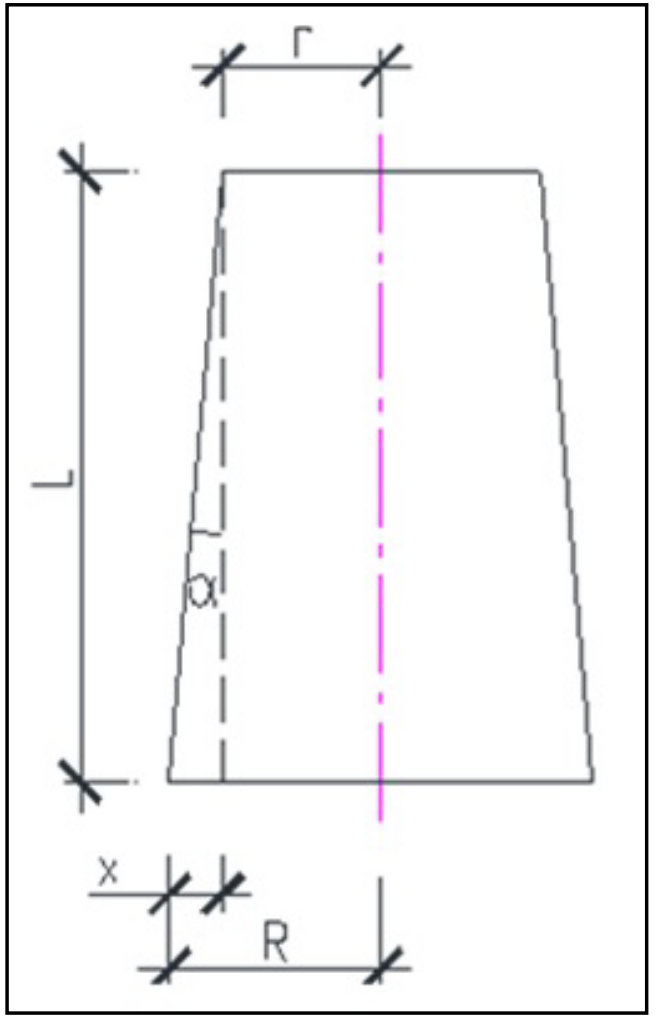

Figure 3. Diagram to the cone area determination

$c=\tau_{f} \cdot 2 \cdot \pi \cdot L \cdot R-d=0$

$D=b^{2}-4 \cdot a \cdot c$

Discriminant of the quadratic equation after transformation will take the form:

$$
\begin{aligned}
& D=\tau_{f}^{2} \cdot \pi^{2} \cdot L^{4}+4 \cdot \sigma_{f} \cdot \pi \cdot L^{2} \cdot\left(\sigma_{f} \cdot \pi \cdot R^{2}-\right. \\
& \left.-\tau_{f} \cdot \pi \cdot L \cdot R+d\right)
\end{aligned}
$$

Roots of the equation will be $\sin \alpha-$ the sine of the slope angle of the upper inverted cone of the pile which is needed for fulfilment of the equilibrium condition of the pile in the soil:

$x_{1,2}=\sin \alpha=\frac{-b \pm \sqrt{D}}{2 \cdot a}$

$$
\begin{aligned}
& x_{2}=\sin \alpha= \\
& =\frac{\left(2 \sigma_{f} \pi R+\tau_{f} \pi L^{2}\right)-\sqrt{\tau_{f}^{2} \pi^{2} L^{4}+4 \cdot \sigma_{f} \pi L^{2}\left(\sigma_{f} \pi R^{2}-\tau_{f} \pi R+d\right)}}{2 \sigma_{f} \pi L^{2}}
\end{aligned}
$$

Technologically, the bored pile with the upper inverted cone is arranged with the help of the casing pipe which has the upper part of the cone shape with the smaller base on the daylight surface. The casing pipe is dipped into the borehole, a reinforcement cage is installed in the design position, a tremic pipe is dipped and pouring of the concrete is performed in one operation with the application of vibrators. After removing the tremic pipe, the casing pipe remains in the borehole for the period of pile concrete maturing the stripping strength. Then the casing pipe is extracted. Backfilling of the upper cone in layers and compaction are performed. Due to the structural features of the pile, the backfilling with the local soil is performed and it does not require delivery of the dry non-heaving soil.

The bottleneck of this method is probable complications with extracting of the casing pipe caused by the adhesion of the solidifying concrete mixture with its internal surfaces. These problems are solved by application of release agents and lubricants, preventing adhesion of the concrete mixture with the pipe material, onto the casing pipe internal surfaces. Before starting works it is needed to perform the corresponding preparation of the casing pipe internal surfaces. In order to prevent the concrete mixture adhesion to the casing pipe, various lubricants are used: "Krystal M22" technological lubricant (Mas Prom company); lubricant agents of the German company "Elaskon Sachsen GmbH \& Co.KG", composite material AXC-0028MP (German company PEMCO) and others.

The sequence of technological operations for arrangement of the pile with the upper inverted cone is shown in Figure 4.

Another variant of the technology is the pile construction with the help of a permanent casing pipe with the upper cone-shaped part. The pipe material is low-cost plastic. Effective features are the possibility to combine technological operations for protection of borehole walls and arrangement of the cone concrete forms, as well as exclusion of the casing pipe extraction operation.

\section{Results}

Thus, the slope angle of the pile inverted cone which is optimal for the neutralization of heaving forces is determined from the condition of pile equilibrium in the soil. Summarizing the research, we will show calculation results of slope angles of the upper inverted cone of piles, installed in the foundation of the same structure under various soil conditions. Initial soil conditions for the calculation of heaving stresses are specified in Table 1. Slope angles of the pile cone " $\alpha$ " at the specified constant load "P" are calculated by equaion (8) taking into account characteristics of soils and frost heaving stresses. The calculation results are represented in Table 2. 


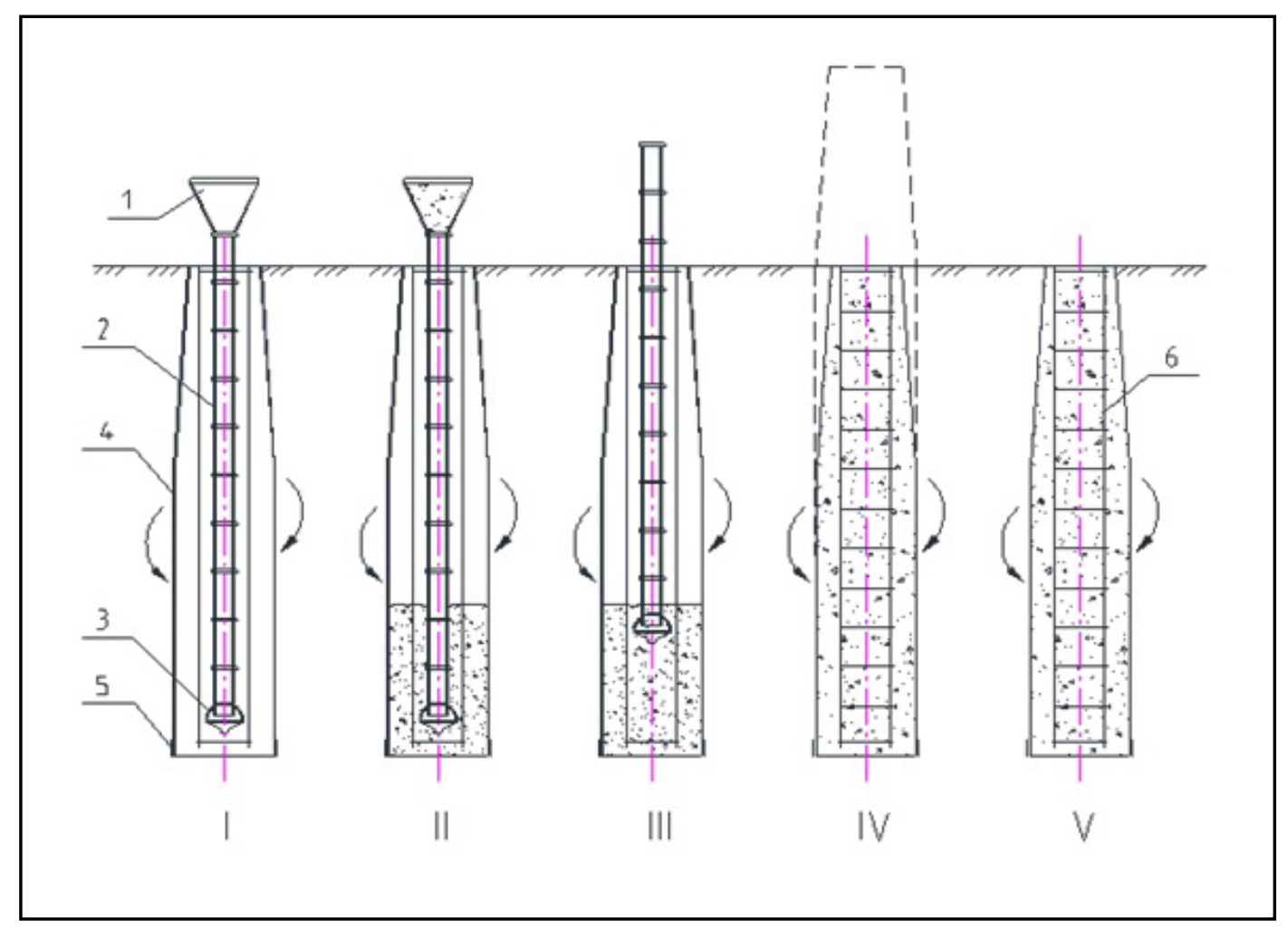

Figure 4. Sequence of operations in the pile concreting:

I - performance of the borehole and installation of the tremic pipe; II - concreting the pile;

III - extracting the tremic pipe; IV - extracting the casing pipe; V — finished pile.

1 - receiving hopper for concrete mixture; 2 - tremic pipe; 3 - quality control device for pouring of con-

crete mixture; 4 - casing pipe; 5 - cutting tip of the casing pipe; 6 - reinforcement cage

Table 1. Characteristics of soils.

\begin{tabular}{|l|l|l|l|l|l|l|l|l|}
\hline $\begin{array}{l}\text { Type of } \\
\text { soil }\end{array}$ & $\begin{array}{l}\text { Specific } \\
\text { weight, } \\
\text { Y, kN/m3 }\end{array}$ & $\begin{array}{l}\text { Natural } \\
\text { humidity, } \\
\text { w, unit } \\
\text { fraction }\end{array}$ & $\begin{array}{l}\text { Plasticity } \\
\text { index, } \\
\text { Lp, unit } \\
\text { fraction }\end{array}$ & $\begin{array}{l}\text { Index of } \\
\text { liquidity, } \\
\text { LL, unit } \\
\text { fraction }\end{array}$ & $\begin{array}{l}\text { Void volume } \\
\text { ratio, } \\
\text { e, unit } \\
\text { fraction }\end{array}$ & $\begin{array}{l}\text { Degree of } \\
\text { humidity, } \\
\text { Sr, unit } \\
\text { fraction }\end{array}$ & $\begin{array}{l}\text { Specific } \\
\text { cohesion, } \\
\text { s, kPa }\end{array}$ & $\begin{array}{l}\text { Deformation } \\
\text { modulus, } \\
\mathrm{E}, \mathrm{MPa}\end{array}$ \\
\hline Sand clay \\
\hline Soil No. 1 & 18.0 & 0.29 & 0.11 & 0.66 & 0.83 & 1.0 & 24 & 7.1 \\
\hline Soil No. 2 & 19.8 & 0.32 & 0.15 & 0.52 & 0.8 & 0.95 & 19 & 9.7 \\
\hline
\end{tabular}

Table 2. Values of slope angles of the pile cone for two types of soil.

\begin{tabular}{|c|c|c|c|c|c|c|c|c|c|c|}
\hline $\begin{array}{l}\text { Type of } \\
\text { soil }\end{array}$ & $D, m$ & $L, m$ & $L_{1}, m$ & $\mathrm{~L}_{2}, \mathrm{~m}$ & $\mathrm{P}, \mathrm{kN}$ & $\mathrm{tf}, \mathrm{kPA}$ & of, kPA & $\mathrm{fi}, \mathrm{kPA}$ & $\begin{array}{l}\mathrm{SP}, \\
\mathrm{cm}^{2} / \\
\text { hour } \cdot{ }^{\circ} \mathrm{C}\end{array}$ & $\alpha$, degree \\
\hline $\begin{array}{l}\text { Soil No. } \\
1\end{array}$ & 0.6 & \begin{tabular}{|l|}
1.0 \\
\end{tabular} & 0.1 & \begin{tabular}{|l|}
1.7 \\
\end{tabular} & 164.3 & 166.64 & 132 & 14.8 & 0.019 & 8.0 \\
\hline $\begin{array}{l}\text { Soil No. } \\
2\end{array}$ & 0.6 & 1.0 & 0.1 & 1.7 & 164.3 & 179.85 & 154 & 20.4 & 0.021 & 8.6 \\
\hline
\end{tabular}




\section{Notes to table 2:}

$\sigma f$ is the normal stress of the soil frost heave on the pile lateral surface (Tretiakova, 2016);

If is the tangential stess of the soil frost heave which is pulling the pile; the value of the tangential frost heaving forces on the pile lateral surface is determined by the author in dependence on humidity and specific adhesion of frozen soil particles (2016);

$f i$ is the calculated resistance of a soil i-layer on the pile lateral surface in the thawed zone;

$S P$ is the segregated soil potential, $\mathrm{cm}^{2} /$ hour $\cdot{ }^{\circ} \mathrm{C}$;

$P$ is the sum of the external load and own pile weight;

$L_{1}$ is the length of the pile section in frozen soil without taking into account the cone;

$L_{2}$ is the length of the pile section in the thawed soil;

$L$ is the length of the pile cone section;

$D$ is the pile diameter;

$\alpha$ is the slope angle of the lateral surface of the pile cone section.

Correspondingly selected geometrical parameters of the pile upper cone provide conditions for formation of the package of retenting forces exceeding the sum of pulling loads, that allows ensuring integrity of above-fundamental structures in any soil conditions.

The suggested variant of the arrangement technology of the pile with the upper inverted cone allows combining operations for protection of borehole walls and arrangement of the concrete form for the inverted cone, that defines its effectiveness.

\section{Conclusion}

The method for protection of buildings and structures in cold regions from the effect of freezing soil is the application of effective piles of the worked out design with increased resistence to pulling-out by the frost heaving forces. This design solution is supported by results of theoretical calculations and in-situ experiments.

Originality and novelty of the solution lies in the use for the frost heave control of forces of the same nature.
Presence of the inverted cone in the pile structure leads to appearance of heaving forces components retenting the pile from rising. The design solution which is reflected in the paper contains the method of practical calculation of pile geometrical characteristics, which are optimal for the heaving forces neutralization in certain soil conditions. This method represents the theoretical contribution into the solution of the problem of decrease in the effect of the frost heaving forces on structures in cold regions.

Practical significance of the research lies in the elimination of additional costs for protection from the frost heave at stages of designing, erection and operation due to the use for this purpose of pile foundations of the structure.

The durability of this design solution in comparison with other methods is obvious.

\section{Discussion}

Despite the fact that theoretical and experimental works for the determination of parameters of the pile under study were carried out, still a number of problems needs to be solved for the wide practical application of such piles in the construction industry.

- The reliability degree of obtained formulas will be higher with the increase in the number of experiments, carried out in different soil conditions. Therefore, it is reasonable to keep on conducting experiments in different climatic areas, to which the phenomenon of the soil frost heave is inherent.

- In order to increase the applicability of formulas in practical designing, the development of calculation software is required. Calculation suites will allow an engineer to avoid labour-intensive calculations, increasing the creative component of desinging process connected with making non-standard alternative decisions, as well as developing this technique. 


\section{References}

Amoco Production Company, (1972). Heave-proof Arctic piling. US3703812.

Babaei, M., Liu, J., Staseff, D. (2016). Numerical analysis of freezing and thawing influence on soil nail walls. In: Proceedings of the CGS GeoVancouver Conference. Vancouver. Available at: https://www.researchgate.net/publication/309668911 (viewed on: 12.01.2017)

Dalmatov, B.I. (1954). Issledovaniia kasatel'nykh sil pucheniia i vliianiia ikh na fundamenty sooruzhenii [Investigation of frost heave tangential forces and their effect on foundations]. Academy of Sciences of the USSR: Institut merzlotovedeniia [Institute of the frost science], $60 \mathrm{p}$. (in Russian)

Dalmatov, B.I., Lapshin, F.K., Rossihin, Ju.V. (1975). Proektirovanie svajnyh fundamentov v uslovijah slabyh gruntov [Design of pile foundations in the soft soil]. Leningrad: Strojizdat. (in Russian)

Dobrynin, A.O. (2012). Fundamenty iz dvukonusnykh svai dlia transportnogo stroitel'stva [Foundations of the piles for the transport construction]. Ph.D. thesis in Engineering Science. Perm: Perm National Research Polytechnic University. (in Russian)

Golli, O.R. (2000). Integral'nye zakonomernosti moroznogo pucheniia gruntov i ikh ispol'zovanie pri reshenii inzhenernykh zadach $v$ stroitel'stve [Integral mechanism of frost heaving of soils and application of them in the performance of the engineering challenges in building]. Doctoral thesis in Engineering Science. Saint Petersburg: B.E. Vedeneev VNIIG, 45 p. (in Russian)

lushkov, B.S., Ponomarev, A.B. (1987). Primenenie pustotelykh konicheskikh svai v grazhdanskom stroitel'stve [hollow tapered pile application in the civil engineering]. In: Proceedings of Osnovaniia i fundamenty v geologicheskikh usloviiakh Ural [Substructures and foundations under the Ural' geologic conditions]. Perm: Perm National Research Polytechnic University. (in Russian)

Karlov, V.D. (1998). Sezonno promerzaiushchie grunty kak osnovaniia sooruzhenii [Seasonal freezing soils as a base of construction]. Doctoral thesis in Engineering Science. Saint Petersburg: SPbSUACE, 349 p. (in Russian)

Kibriya, T., Tahir, L. (2015). Adfreeze forces on Lightly Loaded Pile foundations of Solar PV Farms in Gold Regions. American journal of Civil Engineering and Architecture, 3 (4), pp. 109-117. DOI: 10.12691/ajcea-3-4-1

Medvedeva, O.P. (1992). Rabota piramidal'no-prizmaticheskikh svai v pylevato-glinistykh gruntakh [Pyramidic prismatic pile' action in clay floury soils]. Ph.D. thesis in Engineering Science. Krasnoyarsk, Krasnoyarsk PromStroy NII Project Plc. (in Russian)

Modisette, J.P., Modisette, J.L. (2014). Pipe Line Frost Heave. Pipeline Simulation Interest Group, 1421, pp. 1-8. Available at: https://www.atmosi.com/media/1419/1421-pipeline-frost-heave-or-the-lack-thereof-atmos_psig.pdf (viewed on: 12.01.2017)

Morareskul, N.N. (1950). Issledovanie normal'nykh sil pucheniia gruntov [Investigation of frost heave normal forces]. Ph.D. thesis in Engineering Science. Leningrad: LISI, 26 p. (in Russian)

NIIOSP (Nauchno- issledovatel'skii institut osnovanii i podzemnykh sooruzhenii) [Research institute of foundation and underground constructions], (1980). Rekomendatsii po snizheniiu kasatel'nykh sil moroznogo vypuchivaniia fundamentov s primeneniem plasticheskikh smazok i kremniiorganicheskikh emalei [Recommendations for reducing tangential forces of foundation' bulging with the application of plastic cover and organosilicon enamels]. Moscow: VNIIS Gosstroia SSSR [Russian Research Institute for Certification of the USSR State Committee for Construction]. (in Russian)

Repetskii, D.S. (2011) Rabota dvukonusnykh svai v puchinistykh gruntakh [Biconical pile' action on heaving soil]. Ph.D. thesis in Engineering Science. Perm: Perm National Research Polytechnic University. (in Russian)

Tretiakova, O.V. (2016). Velichiny normal'nykh napriazhenii moroznogo pucheniia, razvivaiushchikhsia v glinistykh gruntakh [The values of the normal stresses of frost heaving, growing in clay soil]. Transport. Transportnye sooruzheniia. Ekologiia [Transport. Traffic construction. Ecology], 1, pp. 125-141. (in Russian) DOI: 10.15593/24111678/2016.01.09 